national accreditation, and prioritize international rankings over local needs and internationally oriented policies over social needs. Internationalization should be conceived as a medium through which institutional quality and education processes are improved in general, and not as an end goal in and of itself.

In conclusion, internationalization processes unquestionably affect academic cultures by establishing new challenges within teaching/learning processes, research, and administrative functions. They also have an impact on how new knowledge is produced and disseminated. While undoubtedly generating tensions and conflict, internationalization should stimulate academics to reevaluate their teaching and research strategies. Similarly, it should improve the quality of higher education and its relevance to local needs-put under pressure by globalization. Instead of imposing external clusters of practices and standards, internationalization should become a support for local decisionmaking at higher education institutions.

DOI: http://dx.doi.org/Io.6oI7/ihe.20I9.97.10940

\title{
Internationalization of In- donesian Higher Education: Recent Initiatives and their Problems
}

\section{Agustian Sutrisno}

Agustian Sutrisno is a lecturer at Atma Jaya Catholic University of Indonesia in Jakarta. He was a Fulbright Visiting Scholar at CIHE at Boston College in 2017. E-mail: agustian.sutrisno@gmail.com.

$\mathrm{I}_{\mathrm{i}}^{\mathrm{n}}$ ndonesian higher education is insular in comparison to 1 its Southeast Asian neighbors, e.g., Singapore, Malaysia, and even Vietnam. Student and staff mobility are low and no international branch campus operates in the country. In early 20I8, two government initiatives-welcoming foreign providers and recruiting international academics-signaled that the situation was about to change. However, lack of progress in those initiatives raises the question of what has blocked the internationalization of Indonesian higher education and what can be done to rectify the situation.

\section{RECENT INTERNATIONALIZATION INITIATIVES}

The first internationalization initiative, welcoming international branch campuses, seeks to bring in quality providers to improve the training of Indonesian human resources. The introduction of these campuses may also bring competition in the higher education sector and stimulate local universities to improve their quality. Nevertheless, statements from different government officials regarding the specific regulations for these campuses were ambiguous. Some said that these campuses could be wholly owned by foreign universities, while others stated that they had to be a joint investment. Indonesian media reported that by mid-2018, ten campuses would be operational, including branches of the University of Cambridge and MIT, which would be located in a special economic zone outside Jakarta. These campuses, it was stated, would be required to teach compulsory Indonesian subjects, such as religious instruction and national ideology, and the courses offered would be limited, mainly, to science, technology, engineering, and mathematics.

The second initiative, World Class Professors, seeks to recruit up to 200 academics from the world's best roo universities. This 2018 initiative is the revamped and extended version of an earlier program launched in 20I7. That first program was deemed successful for bringing in international academics through a sabbatical placement program, lasting for several months, at Indonesian universities. The underlying rationale is to improve the research productivity of Indonesian universities. It is believed that by bringing in highly productive international researchers, Indonesian academics will have collaborative partners who can help increase their research quality and international publications. For this second iteration, the government has set aside approximately US\$I3 million. This means that each international academic is to be paid about US\$4,000-5, , ०० per month for a maximum period of three years. Importantly, the prospects of career improvement are limited as these international academics may not take up managerial positions.

The two initiatives aim to increase the quality of Indonesian higher education through internationalization activities. There seems to be an awareness among policy-makers that knowledge transfer from international universities and academics is needed to improve human resources and boost research productivity and innovation in Indonesian higher education. Hence, internationalization in the Indonesian context is largely synonymous with quality improvement. However, in early 20I9, the progress of these initiatives seems slow, and no international branch campus is operational in the country. 


\section{INHIBITING FACTORS}

The slow progress of internationalization at Indonesian universities can be ascribed to national and organizational problems. At the national level, there is no unified policy on internationalization. The government has been keen to create world-class universities in Indonesia, but the road map has never been made clear. Premature planning and contradictory statements by Indonesian officials regarding the opening of international branch campuses indicate a lack of policy coherence. The rationale for internationalization and its role in the quality improvement of Indonesian higher education remains largely unknown.

At the organizational level, the management of many Indonesian universities has not undergone adequate transformation and a status quo culture is pervasive. Among academics, an entrenched patronage system in some universities may force junior academics to be subservient to the will and direction of senior academics. Innovative junior academics can wait long before securing the opportunity to hold leadership positions and transform the organization. Moreover, university leaders may often be chosen because of their seniority of service, not necessarily because of organizational skills and a proven track record in managing

\section{The slow progress of internationaliza- tion at Indonesian universities can be ascribed to national and organizational problems.}

innovative education programs, let alone internationalization efforts. Consequently, the organizational culture in some universities may not be conducive to fostering staff members who can quickly respond to change. Coupled with the absence of a unified policy, these organizational ailments seem to have turned higher education institutions into sluggish organizations that are reluctant to welcome new internationalization initiatives from the government. In fact, through the mass media, many Indonesian academics opposed the two initiatives above and called them neocolonialist and an unbridled commodification of higher education, without any consideration of the government's goal to improve quality.

\section{The Fate of Internationalization In IN DONESia}

The fate of internationalization of higher education in Indonesia largely depends on national policy-makers and actors at the level of universities. Conceptualized as a part of quality improvement, internationalization holds potential for Indonesian higher education development. If the Indonesian government should be willing to develop a robust internationalization policy as a means to improve the higher education sector, much could be adapted from the policies of neighboring countries. How Malaysia incorporates international branch campuses so that foreign quality providers can absorb unmet demand for higher education can serve as a model, for instance.

However, considering the resistance against internationalization initiatives within Indonesian universities, the biggest issue that Indonesia must tackle is transforming the organizational culture and management of universities. Without major efforts to do so, the future of the Indonesian workforce is in jeopardy. A study done by the Boston Consulting Group in 2013 predicted that Indonesian companies would trail behind in future years, as they were unable to recruit quality talent. By 2020 , recruiting entry-level candidates will be difficult, as only half of the positions will be filled. At the senior management level, the Indonesian workforce will not have enough global exposure and leadership skills to keep up with regional and global competition. To transform the management and culture of universities, Indonesia can learn from the policies of its Asian neighbors. The Chinese 2II and 985 projects have experience that can be contextualized to the Indonesian situation, particularly on how to drive the transformation of key institutions to help them become world-class universities. The willingness to learn from the experiences of its neighbors may hold the key to transforming and internationalizing Indonesian higher education.

DOI: http://dx.doi.org/ıo.6oI7/ihe.20I9.97.I094I5

\section{India Takes Slow Steps toward Internationalization}

\section{PushKar}

Dr. Pushkar is director and chief executive, The International Centre Goa (ICG), India.E-mail: pushkar@incentgoa.com.

$\mathrm{T}$ here is a growing consensus in India among government officials and many university leaders that Indian universities need to improve significantly on the internationalization dimension, especially in terms of international students and faculty. This emerging consensus is in part due to the consistently poor performance of Indian universities in various world university rankings. Only a few Indian institutions count among the top 500 universities 